기 챙 훙 학 잡 지 제30권 제 3 호

The Korean Journal of Parasitology

Vol. 30, No. 3, 183-189, September 1992

\title{
Karyotypes of Pneumocystis carinii from Korean Rats
}

\author{
Sung-Tae Hong ${ }^{1)}$, Beyong Il $\mathrm{Kim}^{21}$, Weon-Gyu Kho ${ }^{1) *}$, Jae-Ran $\mathrm{Yu}^{1) *}$, \\ Jina Kook ${ }^{1)}$, Jong-Yil Chai ${ }^{1)}$, Chong-Ku Yun ${ }^{2)}$ and Soon-Hyung Lee ${ }^{1)}$ \\ Departments of Parasitology $y^{1)}$ and Pediatrics ${ }^{21}$, Institute of Endemic Diseases \\ Seoul National University College of Medicine, Seoul 110-799 Korea
}

\begin{abstract}
Molecular karyotyping was applied to Pneumocystis carinii ( $\mathrm{Pc}$ ) from two strains of experimental rats, Sprague Dawley(SD) and Fisher(F), in Korea. Field inversion gel electrophoresis and contour clamped homogeneous electric field electrophoresis resolved 15 chromosomal bands from the Pc. The size of the bands was estimated $270 \mathrm{~kb}$ to $684 \mathrm{~kb}$ from $\mathrm{SD}$ rats, and $273 \mathrm{~kb}$ to $713 \mathrm{~kb}$ from $\mathrm{F}$ rats. The bands of $283 \mathrm{~kb}$ from SD rats and of $273 \mathrm{~kb}$ from $\mathrm{F}$ rats stained more brightly suggesting duplicated bands. Total number of chromosomes was at least 16, and total genomic size was estimated $7 \times 10^{6} \mathrm{bp}$. All of the bands from $\mathrm{F}$ rats hybridized to the probe of repeated DNA sequences of $P c$ and the band of $448 \mathrm{~kb}$ size was proved to contain rDNA sequences, but Pc. chromosome bands from SD rats showed no reactions tothe probes. The 2 different karyotypes of $P$. carinii from 2 strains of rats were maintained consistently for 2 years.
\end{abstract}

Key words: Pneumocystis carinii, albino rat strain, karyotype strains

\section{INTRODUCTION}

Pneumocystis carinii (Pc) is an important opportunistic pathogen in immune compromised humans over the world (Walzer et al., 1989). Human cases also had been recorded in Korea (Cheong et al., 1983), and the serologic finding by Hong (1991) revealed its saprophytous prevalence among people in Korea.

Taxonomic position of $\mathrm{Pc}$ is still controversial (Frenkel et al., 1990). Furthermore, the basic requirement for in vitro cultivation is not fully

The present study was supported by the Research Grant from the Korea Science and Engineering Foundation (1990).

* Present address: Weon-Gyu Kho, Department of Parasitology, Inje University, Pusan 614-735; Jae-Ran Yu, Department of Parasitology, College of Medicine, Konkuk University, Chungju 380701 . understood yet (Cushion and Ebbets, 1990). The shortage of basic knowledge on the nature of this protist makes further studies difficult. Therefore, more intensive basic researches on the fastidious organism have been required.

Pulsed field gradient gel electrophoresis(PFGE) is a newly introduced method to resolve chromosome-sized DNA molecules in agarose matrix by repeatedly altered direction of electric field (Schwartz and Cantor, 1984; Carle et al., 1986; Chu et al., 1986; Lai et al., 1989). The technique enables us to analyze the chromosomes of the microscopic organisms whose morphological karyotypes are not available. Actually PFGE has provided much information on the chromosomes of important protozoan parasites or fungi.

The karyotyping method had been applied to Pc by 3 research groups(Yoganathan et al., 1989; Lundgren et al., 1990; Hong et al., 1990), and their results showed different karyotypes. 
Furthermore, Hong et al. (1990) found different patterns by the host, rats and humans, and variations even by the colony of experimental animals. These findings suggest that Pc should be a complex group of genetically various organisms though they are indistinguishable microscopically.

In this context, the karyotypic nature of $\mathrm{Pc}$ should be evaluated by various localities and different animals. The present study aimed to observe the karyotypes of $\mathrm{Pc}$ from Korean rats, and to compare with previous findings.

\section{MATERIALS AND METHODS}

1. Induction of $P c$ infection in albino rats: Adult albino rats of Sprague-Dawley (SD) or Fisher (F) strains were suppressed of their immunity by subcutaneous injection of methyl-

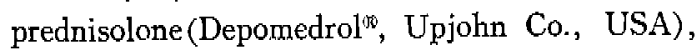
$2 \mathrm{mg}$ each a week. The 2 strains were reared separately with commercial rat diet and tap water mixed with ampicillin. Each batch of the animals contained 20 rats.

\section{Purification of $\mathrm{Pc}$ and embedded lysis} of the cells: The rats kept over 8 weeks were sacrificed and their lungs were removed. The lungs were chopped and homogenized by a stomacher(Stomacher Lab Blender 80, Seward Medical, UK). After filtration through the cotton gauze, host blood cells and pneumocytes were lysed by successive treatment in $0.05 \mathrm{M}$ ammonium chloride and hypotonic solution. The homogenate was filtered through membranes of $10 \mu \mathrm{m}$ pore for further purification. Host DNAs were lysed by DNase I(Boehringer Mannhaim,

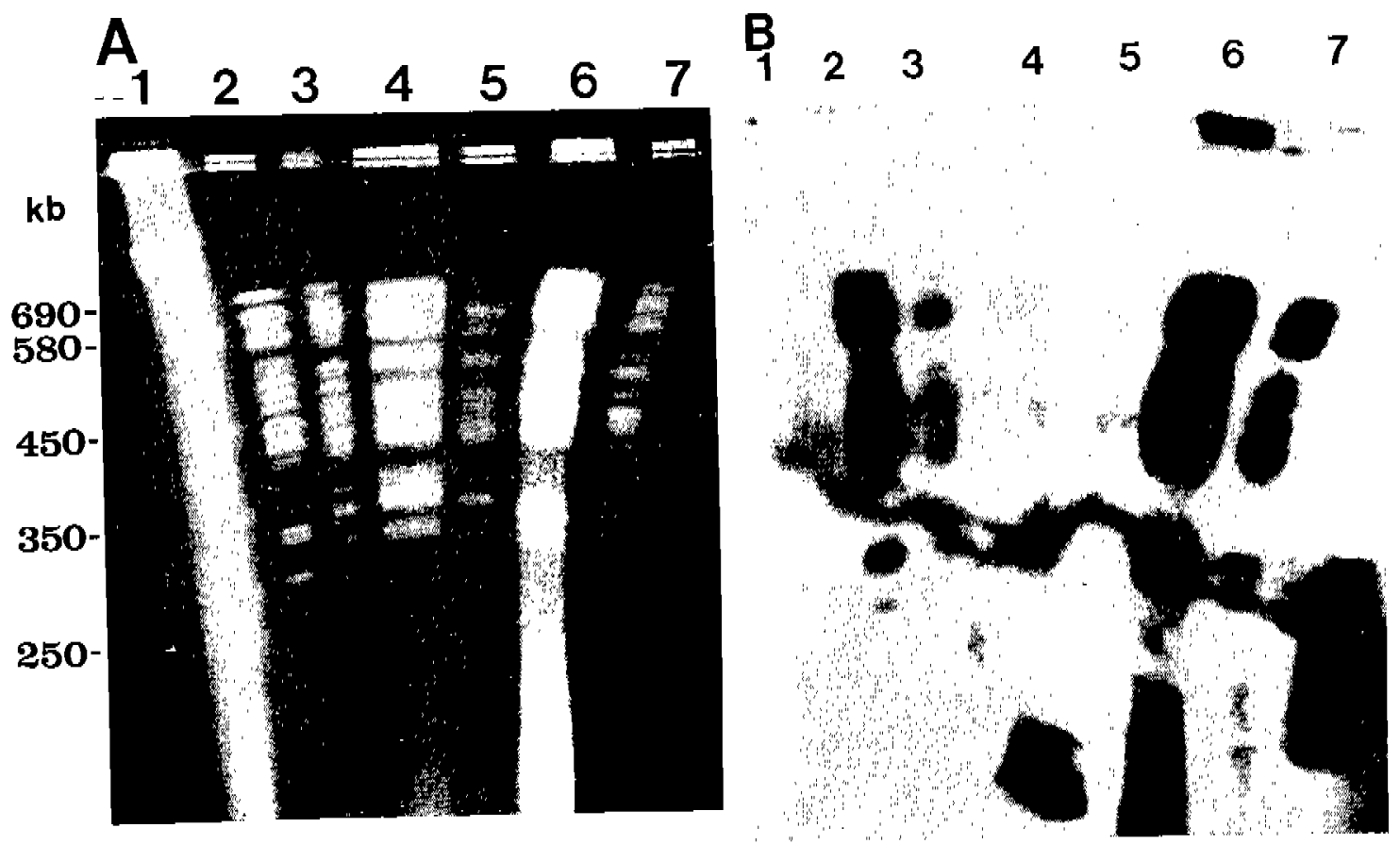

Fig. 1. A: CHEF gol (C15) run in $1 \%$ agarose under $95 \mathrm{~V}$ for $120 \mathrm{hrs}$, initial A time 25 sec, final A time 150 sec, A/B ratio 1, 1/2X TBE buffer at $15^{\circ} \mathrm{C}$. Lanes loaded with size marker and Pneumocystis carinii (Pc) plugs. 1. Saccharomyces cerevisiae AB 972, a size marker; 2. USD6-2, Pc from Sprague Dawley (SD) rats in the USA; 3, UL8-5, Pc from Lewis rats in the USA; 4. SD5-1, Pc from SD rats $(1 / 24 / 91)$; 5. SD8-2, Pc from SD rats $(4 / 12 / 91)$; 6. F14, Pc from Fisher $(F)$ rats $(12 / 31 / 90)$; 7. F15, Pc from $F$ rats $(7 / 12 / 91)$. B: Autoradiograph after hybridization of $\mathrm{P}_{32}$ labeled Rp3-1 probe to the Southern blot of the gel Fig. $1 \mathrm{~A}(\mathrm{Cl})$, exposed to the film after high stringency washing. The lanes 2(USD6-2), 3(UL8-5), 6(F14), and 7(F15) showed strong signals in all bands suggesting that they share common repeat sequences of PC. 
Germany), and the cells were trapped in equal volume of $1.2 \%$ low melting point agarose(BRL Co., USA). The standard concentration of cells was $5 \times 10^{8} / 125 \mu l$. The gels wene treated overnight in $0.25 \mathrm{mg} / \mathrm{ml}$ solution of proteinase $\mathrm{K}$. The gel blocks were stored in refrigerated $0.5 \mathrm{M}$ $\operatorname{EDTA}(\mathrm{pH}$ 9.0) before use.

3. PFGE: PFGE was carried out by contour clamped homogeneots electric field gel electrophoresis(CHEF) and field inversion gel electrophoresis(FIGE). DNA size marker of a yeast (Saccharomyces cerevisiae, AB 972) was loaded on the gels with Pc samples. The standard running conditions were $1 \%$ agarose gel in $0.5 \times$ TBE buffer ( $45 \mathrm{mM}$ Tris, $45 \mathrm{mM}$ boric acid, 125 $\mathrm{mM}$ EDTA) at $15^{\circ} \mathrm{C}$. Further details of switching time were changed by individual gels. The gels were stained with ethidium bromide and observed by UV illumination.

4. Southern transfer and DNA-DNA hybridization: The gels were sequentially soaked in $0.25 \mathrm{M} \mathrm{HCl}, 0.5 \mathrm{M} \mathrm{NaOH}$, and $1.5 \mathrm{M} \mathrm{NaCl}$, and the DNAs in the gel were transfered onto nylon membrane (Nylon 66 plus, Hoefer Scientific, USA) overnight in $6 \times S S C(0.5 \mathrm{M} \mathrm{NaCl}, 0.1 \mathrm{M}$ $\mathrm{NaCi}$ ). The probes were made by nick translation incorporating $\mathrm{P}_{92}$-dATP to rat whole genomic DNA, repetitive sequence DNA(Stringer et al., 1991), and rDNA library (Stringer et al., 1989). Hybridization conditions were as usual in $50 \%$ formamide solution. The radioactivity was visualized by autoradiography. The procedures followed the manual of Sambrook et al. (1989).

\section{RESULTS}

1. Karyotypes: Table 1 listed the parameters of gel blocks of Pc used in this study. CHEF and FIGE separated 15 different chromosomal bands, one of which was stained more intensely than others (Figs. 1,2,3\& 4). The band seemed to be overlapped by two or more molecules of same size, therefore, the chromosomes were 16 at least. The Pc from 2 strains of rats gave different
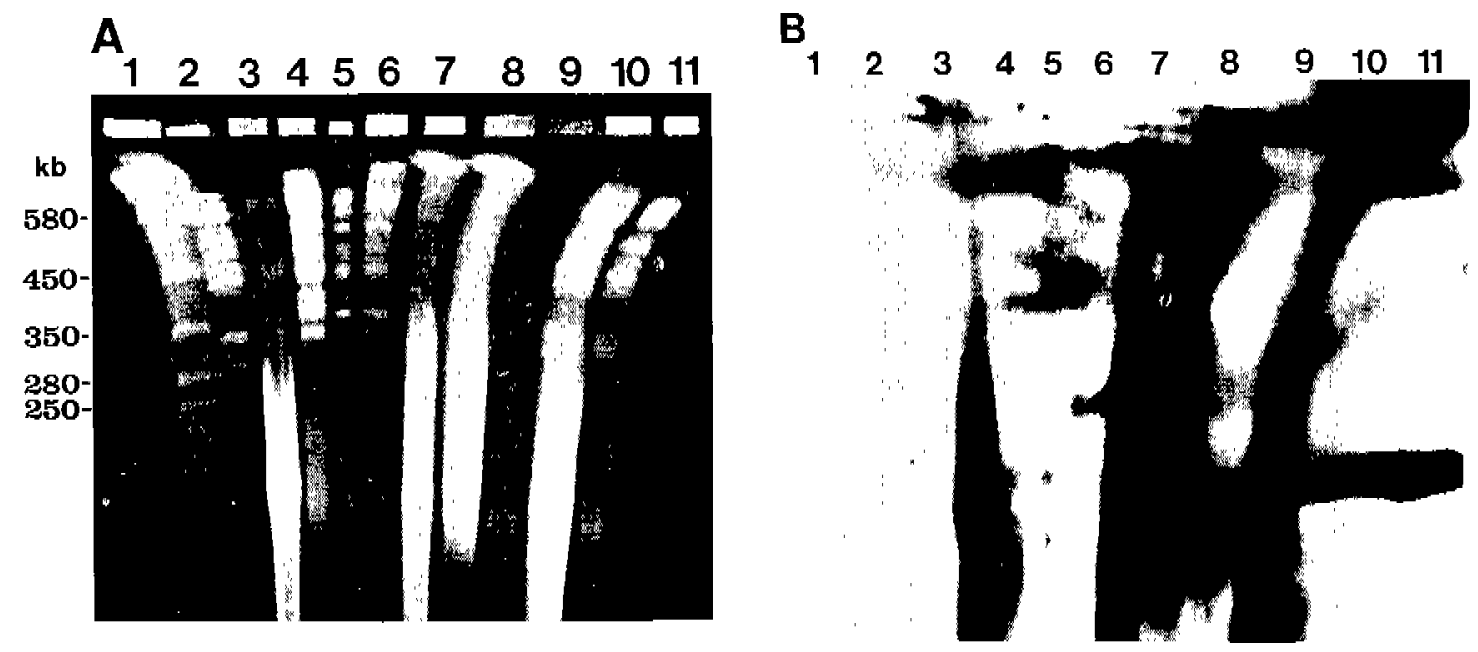

Fig. 2. A: CHEF gel (C13) of $0.8 \%$ agarose run under conditions of $105 \mathrm{~V}, 72 \mathrm{hrs}$, initial A time 25 sec, final A time $110 \mathrm{sec}$, and $1 / 2 \mathrm{X}$ TBE buffer at $15^{\circ} \mathrm{C}$. Loaded plugs are 1. Size marker Saccharomyces cerevisiae $\mathrm{AB}$ 972; 2. USD5-2, Pc from SD rats in the USA; 3. SD3, Pc from SD rats (11/13/90); 4. SD5-2, Pc from SD rats (1/24/19); 5. SD8-1, Pc from SD rats (4/12/91); 6. SD8-2, Pc from SD rats (4/12/91); 7. SD12, Pc from SD rats $(8 / 20 / 91) ; 8, F 1-1$, Pc from F rats $(3 / 26 / 90)$; 9. F1-3, Pc from F rats $(4 / 2 / 90) ; 10$. F14, Pc from F rats $(12 / 31 / 90) ; 11 . \quad F 15, \quad P c$ from F rats (7/12/91). B: Autoradiograph of hybridization of $P_{32}$ labeled rat DNA probe to the blot of Fig. $2 \mathrm{~A}$ (C13) after washing in high stringency solution. Intense signals are observed on the plugs in the trough, megabase-sized bands, and smear backgrounds. The resolved bands between $270 \mathrm{~kb}$ and 700 $\mathrm{kb}$ show no reactions. Also the reactions differ by individual samples. 

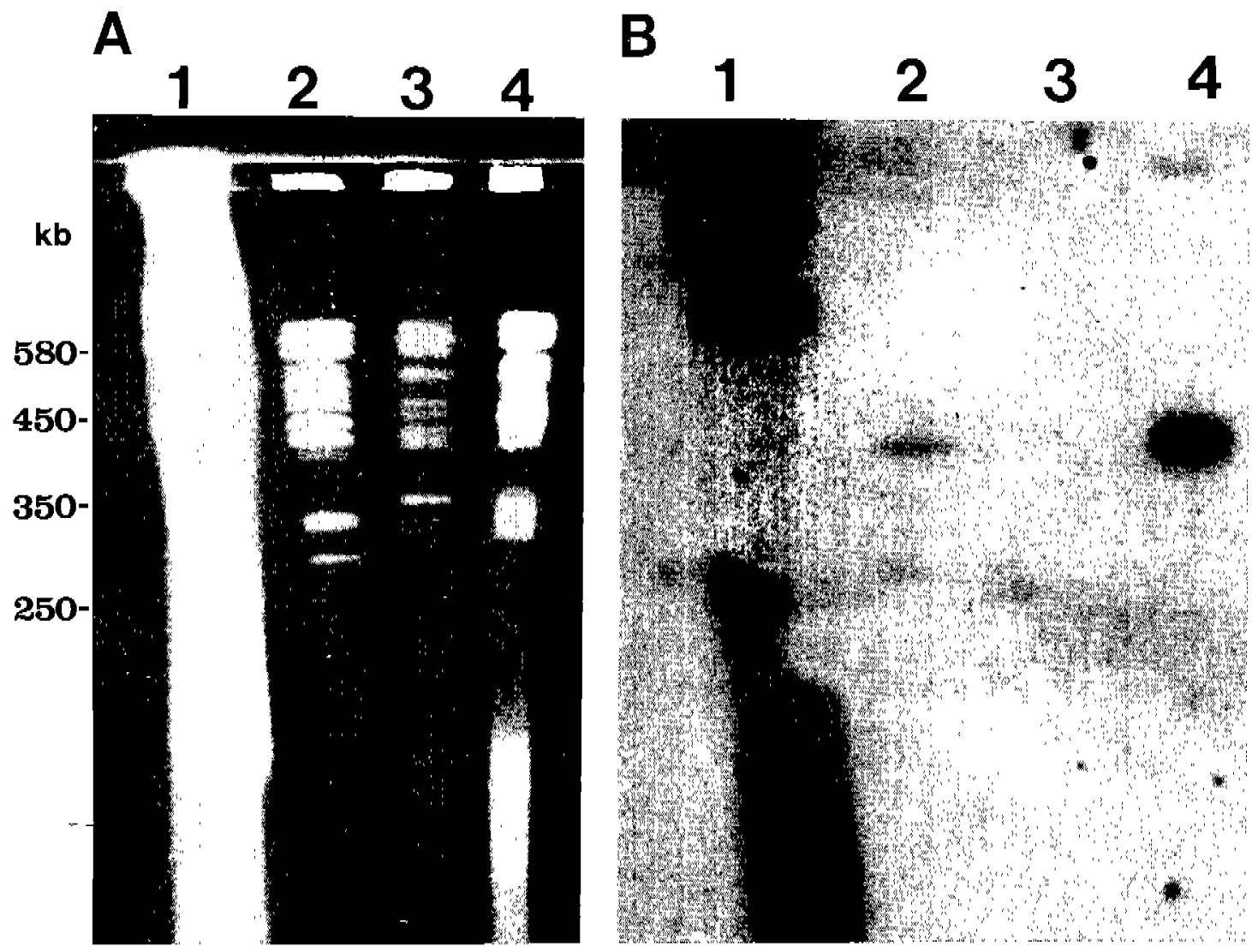

Fig. 3. A: CHEF gel(C14) of $1 \%$ agarose run under the parameters $90 \mathrm{~V}, 96 \mathrm{hrs,}$ initial A time 25 sec, final A time $120 \mathrm{sec}, \mathrm{A} / \mathrm{B}$ ratio $1,1 / 2 \mathrm{X}$ TBE buffer at $15^{\circ} \mathrm{C}$. The samples loaded are 1 . Saccharomyces cerevisiae $\mathrm{AB} 972 ; 2$. USD6-2, Pc from SD rats in the USA; 3. SD8-2, Pe from SD rats (4/12/91); 4. F15, Pe from F rats (7/12/91). B: Autoradiograph of the Fig. 3A(C14) gel blot, hybridized to the probe of 19c-1 rRNA genomic DNA. The $448 \mathrm{~kb}$ band of F15 reacted strongly. The bands of the yeast and one band of USD6-2 also showed signals.

karyotypes, from 270 to $684 \mathrm{~kb}$ in SD group and from 273 to $713 \mathrm{~kb}$ in $\mathrm{F}$ group as estimated by the distance of migration in the gels. The karyotype patterns were schematically shown in Fig. 5. The pattern of each rat strain was maintained same for 2 years. The karyotypes suggest the haploid genomic size of Pc from Korean rats is in the order of $7 \times 10^{6} \mathrm{bp}$.

2. Hybridization: The probe of repetitive sequences(Stringer et al., 1991) hybridized to all of 15 bands in $\mathrm{F}$ samples, but not to those in SD group(Fig. 1). The chromosomal bands from $\mathrm{SD}$ or $\mathrm{F}$ samples showed little signal to the probe of rat genomic DNA. However, the large molecules of megabase size and the smears in the lower part of some samples reacted strongly (Fig, 2). The probe of IDNA hybridized to the band of $448 \mathrm{~kb}$ of F15(Fig. 3), but any band from SD was not visualized.

\section{DISCUSSION}

Yoganathan et al. (1989) applied OFAGE and CHEF to Pc from rats, and observed 16 to 20 bands from $320 \mathrm{~kb}$ to $1.5 \mathrm{Mb}$. Lundgren et al. (1990) obtained 13 chromosomes from rat $\mathrm{Pc}$ by TAFE. Those are different from the present finding, i.e., the former had more bands and larger genomic size and the latter produced less bands.

The karyotypes of $\mathrm{Pc}$ by the present observation are very similar to those of Hong et al. 


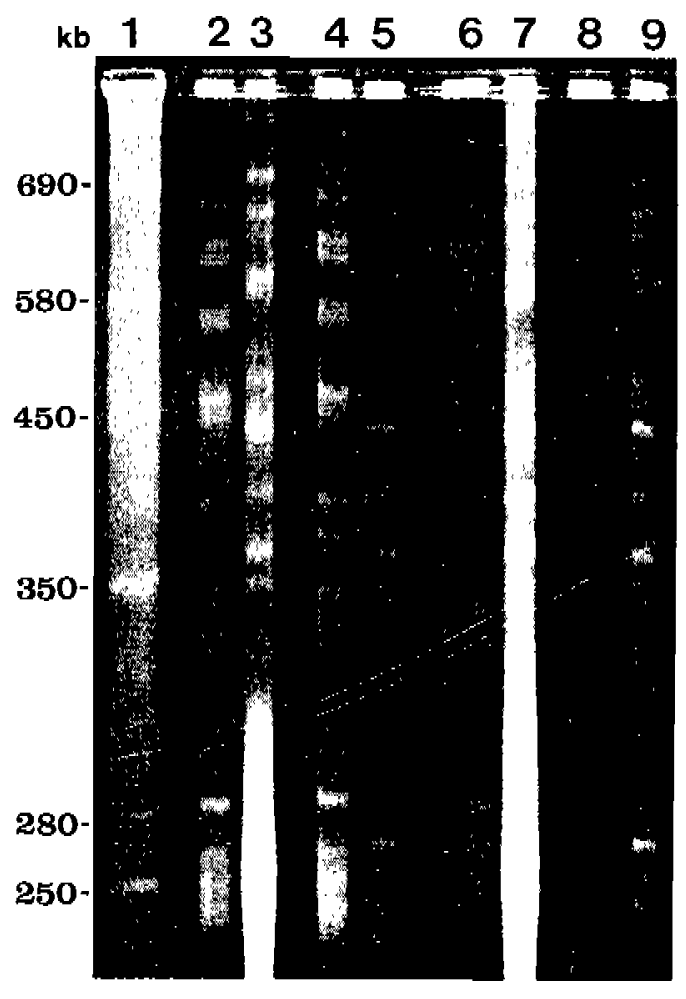

Fig. 4. The FIGE gel, F30, run under conditions of $1 \%$ agarose, $50 \mathrm{sec}$ forward and $25 \mathrm{sec}$ backward, $105 \mathrm{~V}, 96 \mathrm{hrs}$, and $1 / 2 \mathrm{X}$ TBE buffer $14^{\circ} \mathrm{C}$. Loaded samples are 1 . Size marker Saccharomyces cerevisiae $\mathrm{AB} 972 ; 2$. SD8-1; 3. F14; 4. SD8-1; 5. F15; 6. SD82; 7. F14; 8. SD8-2;9. F15.

(1990) in spite of geographical segregation between Korea and the America. Especially the Pc from $F$ rats of the present study has a similar pattern with that of SD rats from America in the number and size range of the chromosomes, genomic size, presence of one duplicated band, location of $\mathrm{xDNA}$ on the 7 th band from the top, and the conserved repeated sequences in all bands. However, they are not exactly same. As found in the figures, each $\mathrm{Pc}$ from American SD rats, American Lewis rats, Korean SD rats, Korean F rats shows different karyotypes.

Variation of the karyotype has been observed in Leishmania (Giannini et al., (1986), Plasmodium (Kemp et al., 1985; Janse et al., 1992), and Candida (Soll et al., 1987 \& 1988; Мerz et al., 1988). The organsims of a species are

\section{SD 8-1}

$\mathbf{k b}$
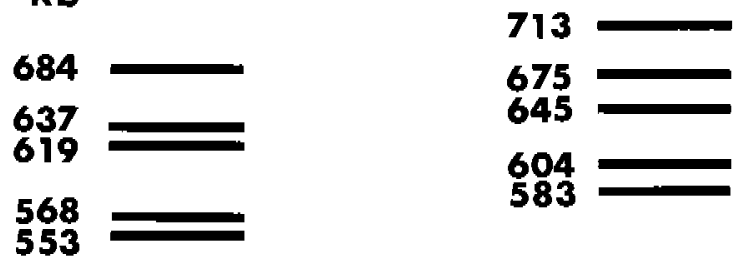

500
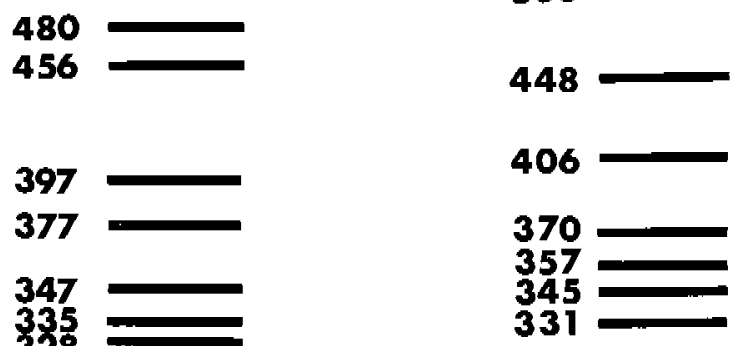

297

283

270

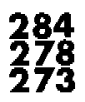

Fig. 5. Estimated size of chromosomal molecular bands resolved from SD8-1 and F15, The $283 \mathrm{~kb}$ band of SD8- 1 and the $273 \mathrm{~kb}$ band of F15 are suggestive of doublet of 2 or more bands of same size.

further subdivided into strains by various characteristics. The strain may be designated by geographical distribution, host species, drug resistance, clinical manifestations, antigenicity, etc. Different strains can represent different karyotypes. Little information, however, is available to match the phenotypic strain and the karyotype variation of any species until now.

In $P$. carinii, no strain has been approved. Although $P c$ are found from various mammals, they are morphologically identical. Only major antigenic determinants are known to be varied between human $\mathrm{Pc}$ and rat $\mathrm{Pc}$ (Peglow et al., 1990). The present finding and Hong et al. (1990)'s observation suggest a strong evidence of Pc's genetic variations. The karyotype variant is suspected to be induced by mutation(Janse et al., 1992). However, the karyotype variation observed in $\mathrm{Pc}$ is not regarded so profound to make genetic diversity. The difference may be 
Table 1. List of Pc samples from albino rats

\begin{tabular}{|c|c|c|c|c|}
\hline Samples & $\begin{array}{l}\text { Date of } \\
\text { sampling }\end{array}$ & Duration & $\begin{array}{l}\text { No. } \\
\text { rats }\end{array}$ & No. of nuclei \\
\hline \multicolumn{5}{|c|}{ Sprague-Dawley rats } \\
\hline S D 1 & $4 / 24 / 90$ & $6 \mathrm{w}$ & 3 & $2 \times 10^{8}$ \\
\hline SD 2 & $.9 / 24 / 90$ & $7 \mathrm{w}$ & 3 & $1 \times 10^{9}$ \\
\hline SD 3 & $11 / 13 / 90$ & $9 w$ & 1 & $1.1 \times 10^{9}$ \\
\hline SD 4 & $12 / 14 / 90$ & $9 w$ & 2 & less than $10^{6}$ \\
\hline \$D 5 & $1 / 24 / 91$ & $11 \mathrm{w}$ & 3 & $5,4 \times 10^{8}$ \\
\hline SD 6 & $4 / 5 / 91$ & $9 w$ & 4 & $4.7 \times 10^{7}$ \\
\hline SD 7 & $4 / 5 / 91$ & $5 \mathrm{w}$ & 2 & less than $10^{6}$ \\
\hline S D8-1 & $4 / 12 / 91$ & $6 \mathrm{w}$ & 6 & $3.8 \times 10^{8}$ \\
\hline S D 8-2 & $4 / 12 / 91$ & $6 \mathrm{w}$ & 12 & $1.1 \times 10^{9}$ \\
\hline SD 9 & $6 / 17 / 91$ & $5 w$ & 4 & less than $10^{6}$ \\
\hline SD D 10 & $7 / 3 / 91$ & $5 w$ & 7 & Not counted \\
\hline SDIl & $7 / 26 / 91$ & $9 w$ & 8 & $7.5 \times 10^{8}$ \\
\hline S D 12 & $8 / 20 / 91$ & $7 \mathrm{w}$ & 14 & 4. $2 \times 10^{7}$ \\
\hline SDl3 & $8 / 28 / 91$ & $6 \mathrm{w}$ & 6 & less than $10^{6}$ \\
\hline \multicolumn{5}{|c|}{ Fisher rats } \\
\hline F 1-1 & $3 / 26 / 90$ & $8 w$ & 1 & $1 \times 10^{\mathrm{B}}$ \\
\hline F $1-2$ & $3 / 26 / 90$ & $8 w$ & 1 & $1 \times 10^{8}$ \\
\hline F $1-3$ & $4 / 2 / 90$ & $9 w$ & 1 & $2.9 \times 10^{10}$ \\
\hline F 2-1 & $6 / 1 / 90$ & $9 \mathrm{w}$ & 3 & $2.2 \times 10^{8}$ \\
\hline F $2-2$ & $6 / 12 / 90$ & $10 w$ & 1 & $1 \times 10^{8}$ \\
\hline F 3-1 & $1 / 10 / 91$ & $9 \mathrm{w}$ & 2 & $2.6 \times 10^{8}$ \\
\hline F $3-2$ & $1 / 10 / 91$ & $9 w$ & 1 & $2.8 \times 10^{8}$ \\
\hline F 12 & $5 / 2 / 91$ & $12 \mathrm{w}$ & 5 & $6.5 \times 10^{7}$ \\
\hline F 13 & $5 / 9 / 91$ & $13 w$ & 6 & $1.5 \times 10^{7}$ \\
\hline F 14 & $7 / 5 / 91$ & $8 w$ & 5 & $2.1 \times 10^{8}$ \\
\hline F 15 & $7 / 12 / 9 \mathrm{I}$ & $3 w$ & 11 & $2.4 \times 10^{9}$ \\
\hline
\end{tabular}

only superficial by aberrant deletion, superimposition, or translocation of the telomere between chromosomes. More data should be filed for further interpretation. Furthermore, the bands from SD Pc were hardly hybridized to the probes of repeated sequences or rDNA. Since the gels contained enough amount of DNA for the hybridization, the organisms from SD rats seemed to share no sequence homology with $\mathrm{Pc}$ from $F$ rats. This should be a subject for further clarification.

Although the biological meaning of karyotype variation is still uncertain in $\mathrm{Pc}$, it may be one of differential indices of strains. Since PFGE is an excellent tool to trace the same karyotype strain, it can prove the transmission modus and spreading course of Pc. Also it may supply fundamental information for its taxonomy when genetic mapping is achieved.

\section{REFERENCES}

Carle, G.F., Frank, M. and Olson, M.V. (1986) Electrophoretic separation of large DNA molecules by periodic inversion of the electric field. Science, 232:65-68.

Chu, G., Vollarth, D. and Davis, R.W. (1986) Separation of large DNA molecules by contourclamped homogeneous electric fields. Science, 234: 1582-1585.

Cheong, S.K., Im, C.B., Ahn, D.H. and Sohn, K.C. (1983) Pneumocystis carinii pneumonia in an institution for adoption. J. Korean Med. Assoc., 26(4):329-336 (in Korean).

Cushion, M.T. and Ebbets, D. (1990) Growth and metabolism of Pneumocystis carinii in axenic culture. J. Clin. Microbiol., 28(6):1385-1394.

Frenkel, J.K., Barlett, M.S. and Smith, J.W. (1990) RNA homology and the reclassification of $P_{n e u}$ mocystis. Diagn. Microbiol. Infect. Dis., 13:1-2,

Giannini, S.H., Schittini, M., Keithly, J.\$., Warburton, P.W., Cantor, C.R. and Van der Ploeg, L.H. T. (1986) Karyotype analysis of Leishmania species and its use in classification and clinical diagnosis. Science, 232:762-765.

Hong, S. T. (1991) Serologic response to Pneumocystis carinii of Seoul National University Hospital patients. Korean J. Parasit., 29(4):355-361.

Hong, S.T., Steele, P.E., Cushion, M.T., Walzer, P.D., Stringer, S.L. and Stringer, J.R. (1990) Pneumocystis carinii karyotypes. J. Clin. Microbiol., 28(8):1785-1795.

Janse, C.J., Ramesar, J., Van Den Berg, F.M. and Mons, B. (1992) Plasmodium berghei: In vito generation and selection of karyotype mutants and non-gametocyte producer mutants. Exp. Parasitol., 74:1-10.

Kemp, D.J., Corcoran, L.M., Coppel, R.L., Stahl, H.D., Bianco, A.E., Brown, G.V. and Anders, R.F. (1985) Size variation in chromosomes from independent cultured isolates of Plasmodium falciparum. Nature, 315:347-350.

Lai, E., Birren, B.W., Clark, S.M., Simon, M.I. and Hood, L. (1989) Pulsed field gel electrophoresis. Biotechniques, $7: 34-42$.

Lundgren, B., Cotton, R., Lundgren, J.D., Edman, 
J.C. and Kovacs, J.A. (1990) Identification of Pneumocystis carinii chromosomes and mapping of five genes. Inf. Immun., 58(6):1705-1710.

Merz, W.G., Connelly, C. and Hieter, P. (1988) Variation of electrophoretic karyotypes among clinical isolates of Candida albicans. J. Clin. Microbiol., 26:842-845.

Peglow, S., Smulian, A.G., Linke, M.J., Pogue, C.L., Nurre, S., Crisler, J., Phair, J., Gold, J.W. M., Armstrong, D. and Walzer, P.D. (1990) Serologic responses to Pneumocystis carinii antigens in health and disease. J. Inf. Dis., 161:296-306.

Sambrook, J., Fritsch, E.F. and Maniatis, T. (1989) Molecular Cloning. A Laboratory Manual 2nd Ed. Cold Spring Harbor Laboratory Press.

Schwartz, D.C. and Cantor, C.R. (1984) Separation of yeast chromosome-sized DNAs by pulsed field gradient gel electrophoresis. Cell, $3^{\prime}$ : 67-75.

Soll, D.R., Langtimm, C.J., McDowell, J., Hicks, J. and Galask, R. (1987) High frequency switching in Candida strains isolated from vaginitis patients. J. Clin. Microbiol, 25:1611-1622.
Soll, D.R., Staebell, M., Langtimm, C., Pfallen, M., Hicks, J. and Gopala Rao, T.V.(1988) Multiple Candida strains in the course of a single systemic infection. J. Clin. Microbiol., 26:1448-1459.

Stringer, S. L., Hong, S.T., Giuntoli, D. and Stringer, J.R. (1991) Repeated DNA in Pneumocystis carinii. J. Clin. Microbiol., 29(6):1194-1201.

Stringer, S.L., Stringer, J.R., Blase, M.A., Walzer, P.D. and Cushion, M.T. (1989) Pneumocystis carinit: Sequence from tibosomal RNA implies a close relationship with fungi. Exp. Parasit., 68: 450-461.

Walzer, P.D., Kim, C.K. and Cushion, M.T. (1989) Pneumocystis carinii. Parasite Infections in the Compromised Host. Marcel Dekker, Inc. New York and Basel.

Yoganathan, T., Lin, H. and Buck, G.A. (1989) An electrophoretic karyotype and assignment of ribosomal genes to resolved chromosomes of Pneumocystis carinii. Molecul. Microbiol., 3:14731480.

\title{
$=$ 국문초록 $=$
}

\section{한국산 힌쥐 카리니주폐포자충의 핵형}

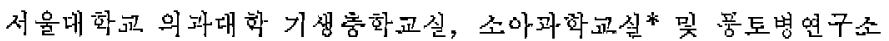 \\ 홍성태 · 긴 병일* · 고원규 · 유제 란 - 국진 아 - 채종일 · 운종구* - 이순형
}

한국 내에서 사욱 공급하는 실헙실옹 현직를 실헐적으로 면역억체하여 Pneumocystis carinii (Pc)를 발현시키 코, 이를 순슥하게 모아서 전기 형동을 이 용한 핵 형을 분석하였 다. Field Inversion Gel Electrophoresis와 Contour Clamped Homogeneous Electric Field Electrophoresis를 사웅하여 분러한 염 색.체 밴드는 Sprague Dawley(SD) 와 Fisher $(\mathrm{F})$ 계 훤쳑 모두에서 15개 식 이었다. 크기는 SD 횐쳐의 경우 $270 \sim 684 \mathrm{~kb}, \mathrm{~F}$ 횐최에서 얻은 포본에서 $273 \sim 713 \mathrm{~kb}$ 에 있었다. 의 중헤서 SD 횐궈에서 얻은 것은 $283 \mathrm{~kb}$ 의 염색체 가, $\mathrm{F}$ 횐줘외 표본은 $273 \mathrm{~kb}$ 의 염 색체 가 특히 강하게 염색되어 두 개 이상의 같은 크기 분자가 중첩된 것으로 보인다. 그러드로 전체 염색체는 회소 한 16 개이며 각 염색체의 크기로 계신된 염섹체 내 전케 유전자의 크기는 $7 \times 10^{6} \mathrm{bp}$ 의 수준에 있다. F현쥐에서 유래한 $\mathrm{Pc}$ 는 전 염색체 분자가 공유하는 반복 엄기서열을 가지며, $448 \mathrm{~kb}$ 열색체가 $\mathrm{rRNA}$ 의 우ㅈㅓㅓㄴ자를 갖고 있었 다. 그러나 $\mathrm{SD}$ 횐쥐의 $\mathrm{Pc}$ 보본에서는 어느 염색체 분자에서도 반복 염기서열과 $\mathrm{rRNA}$ 유전자를 확인하지 못하였 다. 두 개의 횐줘 계통 군은 가각 2년간 같은 핵형의 $\mathrm{Pc}$ 를 유지하였다. (이 연구는 한국과학재단 1990 년도 일반 과체 연구비 지원에 의하혀 수행되었음)

[기생충하잡지, $30(3): 183-189,1992$ 녈 9월] 